\title{
Interactive effects of omnivorous fish and nutrient loading on net productivity regulation of phytoplankton and periphyton
}

\author{
Rafael Dettogni Guariento, ${ }^{1, *}$, Luciana Silva Carneiro ${ }^{1,4}$, Adriano Caliman ${ }^{1,4}$, \\ Reinaldo Luiz Bozelli ${ }^{1}$, João José Fonseca Leal ${ }^{1,2}$, Francisco de Assis Esteves ${ }^{1,3}$ \\ ${ }^{1}$ Universidade Federal do Rio de Janeiro (UFRJ), Laboratório de Limnologia, Av. Brigadeiro Trompowski s/n, CCS, \\ Ilha do Fundão, Rio de Janeiro, CX Postal: 68020; 21941-590, Brazil \\ ${ }^{2}$ Centro Federal de Educação Tecnológica (CEFET) de Química De Nilópolis/RJ, Rua Lucio Tavares, 1045, Centro-Nilópolis, \\ 26530-060, Brazil \\ ${ }^{3}$ Núcleo em Ecologia e Desenvolvimento Sócio-Ambiental de Macaé (NUPEM/UFRJ), São Jose do Barreto, Macaé, \\ CX Postal: 119331 (Agência Correio de Macaé), Brazil \\ ${ }^{4}$ Present address: Universidade Federal do Rio Grande do Norte, Centro de Biociências, Departamento de Botânica, \\ Ecologia e Zoologia, 59072-970, Natal, RN, Brazil
}

\begin{abstract}
Top predators and nutrient loading are key components in the regulation of community structure and biomass in aquatic ecosystems. However, few studies have addressed how these 2 components interact to determine metabolic variables of the community, such as oxygen production and respiration rates. The pelagic zone has been the focus of most research on trophic cascades. Nevertheless, recent data increasingly show the importance of periphyton to the functioning of lakes. We conducted a fully factorial field experiment in enclosures within a humic coastal lagoon to analyze the interacting effects of nutrient addition ( $\mathrm{N}$ and $\mathrm{P}$ ) and the presence/absence of omnivorous fish on phytoplankton and periphyton net primary productivity. Fish presence positively affected net planktonic productivity, especially when nutrients were added. However, fish presence negatively affected net periphytic productivity, probably due to 2 non-exclusive mechanisms: the increase in competition with phytoplankton, which was released from zooplankton grazing, and the direct periphytic biomass consumption by fish. We conclude that fish can alter fundamental ecosystem processes in lakes, such as internal carbon dynamics, by increasing the relative importance of pelagic to periphyton productivity.
\end{abstract}

KEY WORDS: Trophic cascade $\cdot$ Aquatic metabolism $\cdot$ Cross-habitat linkage $\cdot$ Food web $\cdot$ Shallow lake

Resale or republication not permitted without written consent of the publisher

\section{INTRODUCTION}

Numerous studies have documented that both bottomup and top-down forces simultaneously influence community structure and trophic level biomass (Polis \& Strong 1996). However, only very few studies have evaluated the interaction of these mechanisms on ecosystem metabolism, such as the rate of oxygen production or the carbon flow within or across habitat compartments (Schindler et al. 1997, Cole et al. 2000).
In aquatic ecosystems, primary production is frequently limited by the supply of certain nutrients, and the extent to which the nutrient supply increases algal biomass is under partial control of the food web (Hillebrand 2002, Darcy-Hall 2006). For example, in the pelagic zone of lakes, highly abundant large-bodied zooplankton can crop new primary production, which suppresses blooms and prevents or reduces further increases in primary production (Mazumder \& Lean 1994). These phytoplankton consumers can, in turn, be 
controlled by the community structure of their major predators, particularly planktivorous fish. Consequently, food web structure can indirectly regulate primary production through trophic cascading effects (Schindler et al. 1997). However, a recent synthesis has shown that the strength of cascading trophic interactions is highly unpredictable and may show high variation across different ecosystems and habitats (Shurin et al. 2002). Cascading effects have been shown to be frequently weak at lower trophic levels (Elser \& Goldman 1991, Darcy-Hall 2006) and or under high degree of omnivory (Bascompte et al. 2005).

Despite the fact that trophic interactions in the pelagic zone, especially the phytoplankton-zooplankton interaction, have been the center of most of the research on cascading trophic effects, the recognition of the importance of the littoral zone, including aquatic macrophytes and periphyton, to the structure and function of lake communities has been increasing in the past years (Wetzel 1990, Vadeboncoeur et al. 2002). Although littoral and pelagic producers may respond similarly to nutrients or food-web effects, the outcome of these factors may be not straightforward when these producers are analyzed together (Flöder et al. 2006). Phytoplankton biomass increases with increasing nutrients (Huszar et al. 2006), causing decreased water transparency, and thus negatively affecting periphyton growth (Hansson 1992). This decrease leads to weak or unimodal positive relationships between periphyton biomass (chl a) and lake trophic status (Hansson 1992, Liboriussen \& Jeppesen 2006). However, periphyton can make substantial contributions to whole-lake production such as coastal lagoons where the high perimeter:volume ratio and the shallowness provide favorable conditions for the development of a large littoral region (Kjerfve 1994), and hence a large amount of substrata for periphyton colonization (Schindler \& Scheuerell 2002). On the other hand, coastal lagoons offer favorable conditions for heterotrophy due to the typically high concentration of humic-dissolved carbon that originate from the terrestrial surrounding vegetation (Guariento et al. 2009). The high availability of dissolved carbon, in combination with oligotrophy, results in a large relative biomass as well as higher carbon flux through bacteria, compared to primary producers (Cotner \& Biddanda 2002, Guariento et al. 2009), even for periphytic communities, making coastal lagoons large $\mathrm{CO}_{2}$ sources.

In the present study, we conducted a manipulative field experiment in aquatic enclosures to analyze the individual and interactive effects of nutrients and a multi-chain omnivorous fish (Hyphessobrycon bifasciatus), on the net productivity of phytoplankton and periphyton in a shallow oligo-mesotrophic coastal lagoon in southeast Brazil. Multi-chain omnivorous organisms (sensu Vadeboncoeur 2002) are 'generalist predators that exploit multiple food chains based on different primary producer functional groups (e.g. phytoplankton and periphyton), including detritus'. Specifically, we aimed to test the following hypotheses: (1) due to a stronger cascade effect, fish effects on phytoplankton net primary productivity will be greater under non-limiting nutrient conditions and (2) fish presence allows the accumulation of pelagic algal biomass enhancing the asymmetry between phytoplankton and periphyton net productivity but decreasing periphyton net productivity.

\section{MATERIALS AND METHODS}

Experimental site. The study was carried out in Cabiúnas Lagoon, located at Restinga de Jurubatiba National Park, Rio de Janeiro, Brazil $\left(22^{\circ} 15^{\prime} \mathrm{S}\right.$, $41^{\circ} 40^{\prime} \mathrm{W}$ ). Cabiúnas is a pristine oligo-mesotrophic freshwater coastal lagoon, separated from the sea by a sand bar, with a surface area of $0.35 \mathrm{~km}^{2}$ and a mean depth of $2.0 \mathrm{~m}$. Similar to other neotropical coastal lagoons (Esteves et al. 2008), the water is humic and slightly acidic (pH 5.8 to 6.7 ) with an average concentration of dissolved organic carbon (DOC) of $20 \mathrm{mg} \mathrm{l}^{-1}$ and an average annual temperature of $23.6^{\circ} \mathrm{C}$. Cabiúnas is surrounded by a natural 'restinga' ecosystem, which is characterized by coarse-sand soil and bushy vegetation. Its highly permeable watershed and dendritic morphometry favour a great input of terrestrial dissolved organic matter, which represents a major source of DOC to the lagoon. Table 1 summarizes these parameters on an annual basis. During the 7 wk study period, mean water total phosphorus (TP) and total nitrogen (TN) were 1.5 and $20 \mathrm{\mu mol} \mathrm{l}^{-1}$, respectively. Mean phytoplankton biomass estimated by chl a was $30 \mu \mathrm{g} \mathrm{l}^{-1}$, and mean Secchi disc depth was $0.6 \mathrm{~m}$. Enclosures were placed close to the lagoon's littoral region which supports dense stands of the broadleaved cattail Typha domingensis Pers., but no macrophytes were enclosed during the settlement of the enclosures. The littoral region is colonized by many

Table 1. Cabiúnas Lagoon. Water parameters (means $\pm \mathrm{SD}$ ) from January to December 2009

\begin{tabular}{|lc|} 
Water temperature $\left({ }^{\circ} \mathrm{C}\right)$ & $23.6 \pm 0.9$ \\
Transparency as Secchi depth $(\mathrm{m})$ & $0.8 \pm 0.25$ \\
Depth $(\mathrm{m})$ & $2.0 \pm 0.01$ \\
Total phosphorus $(\mathrm{TP})\left(\mu \mathrm{mol} \mathrm{l}^{-1}\right)$ & $1.26 \pm 0.33$ \\
Total nitrogen $(\mathrm{TN})\left(\mu \mathrm{mol} \mathrm{l}{ }^{-1}\right)$ & $22.53 \pm 6.46$ \\
Dissolved organic carbon $(\mathrm{DOC})\left(\mathrm{mg} \mathrm{l}^{-1}\right)$ & $20.0 \pm 3.0$ \\
$\mathrm{pH}$ & $6.1 \pm 0.5$ \\
Chlorophyll $\mathrm{a}\left(\mathrm{g} \mathrm{l} \mathrm{l}^{-1}\right)$ & $23.7 \pm 6.1$ \\
\hline
\end{tabular}


species of freshwater snails. The most abundant herbivorous benthic invertebrate is the gastropod Biomphalaria tanegophila (d'Orbigny 1985), which relies on periphyton as the main component of its diet (Thiengo et al. 2002).

Enclosures. Enclosures consisted of transparent plastic cylinders (2.0 m diameter, $2.4 \mathrm{~m}$ height). They were equipped with iron rings at the top and bottom for structural stability, and to attach floaters (top) and anchors to the sediment (bottom). All enclosures were open at the bottom to allow fish access to benthic food, but were pushed down $0.1 \mathrm{~m}$ into the sediment to prevent fish from escaping. All enclosures were placed at the mean depth of $\sim 2 \mathrm{~m}$, so that the top ring of the enclosures reached $0.3 \mathrm{~m}$ above the water surface protecting the enclosures against lagoon water ingression due to wave action. At this depth, the enclosed water volume was $\sim 63001$.

Experimental design. The experimental framework followed a $2 \times 2$ orthogonal whole factor combination ( \pm nutrients and \pm fish). Treatments were replicated 4 times in each possible combination: (1) Ctrl (no fish, no nutrient addition); (2) Fish (only fish addition); (3) Nut (only nutrient addition); (4) Fish+Nut (both fish and nutrient addition), resulting in 16 field enclosures. To evaluate potential influences of spatial heterogeneity, whole factor treatments were distributed into 4 spatial experimental blocks.

Experimental setup. In the treatments with nutrient addition, the final concentrations of inorganic forms of nitrogen $(\mathrm{N})$ and phosphorus $(\mathrm{P})$ were kept constant throughout the experiment at $50 \mu \mathrm{M}$ of $\mathrm{N}$ (weekly adjusted with $\mathrm{NH}_{4} \mathrm{NO}_{3}$ ) and $10 \mu \mathrm{M}$ of $\mathrm{P}$ (weekly adjusted with $\mathrm{KH}_{2} \mathrm{PO}_{4}$ and $\mathrm{K}_{2} \mathrm{HPO}_{4}$ at 1:1 ratio to minimize $\mathrm{pH}$ alterations). To keep these concentrations constant, inorganic nutrient concentrations were assessed weekly and adjusted to the proper concentrations based on experimental standards. Fish density was manipulated by introducing 40 adult individuals of Hyphessobrycon bifasciatus (Ellis, 1911) (Characidae) into the enclosures achieving a final density of 13 ind. $\mathrm{m}^{-2}$, which is similar to that found in the littoral region of the Cabiúnas lagoon (Sánchez-Botero et al. 2008). Fish were caught near the study location with a net and were conditioned for $1 \mathrm{~d}$ in a fish tank-net inside the lagoon to allow for recovery from the stress associated with capture. Only active and healthy individuals were used in the experiment. They varied in size from 3 to $3.5 \mathrm{~cm}$ (standard length, SL) and in biomass from 0.3 to $0.5 \mathrm{~g}$ ind.$^{-1} H$. bifasciatus is omnivorous. It forages on both pelagic and benthic food webs and can feed on zooplankton, phytoplankton, periphyton or detritus, but feeds predominantly on juvenile planorbid molluscs with $<0.3 \mathrm{~cm}$ shell size because larger animals cannot be eaten due to gape limitation. Moreover, this snail species is ubiquitous in many South American freshwater ecosystems (Carvalho \& Bertaco 2006) and shows a broad foraging distribution throughout the water column. Fish mortality was $<10 \%$ throughout the experiment, as observed daily on enclosure inspection. Dead fish were immediately replaced by living ones, keeping fish density constant throughout the experiment. To account for the spatial heterogeneity in periphyton distribution, thin plastic tiles $\left(15 \times 10 \mathrm{~cm}^{2}\right)$ serving as periphyton substrates were placed $1.0 \mathrm{~m}$ apart in a radial arrangement along the enclosure wall $0.4 \mathrm{~m}$ below the water surface, allowing grazers to forage on them. This depth was chosen because the light intensity at $0.4 \mathrm{~m}$ is not high enough to promote photorespiration and is somewhat far from the light saturation point (ca. $0.8 \mathrm{~m}$ ) for the periphyton assemblage at Cabiúnas Lagoon (Guariento et al. 2009) and thus does not specifically favor autotrophic nor heterotrophic processes. We mixed the water column in the enclosures twice a week to homogenize nutrients, oxygen and temperature and to minimize seston settlement (Stephen et al. 2004). Per enclosure, 1 tile was sampled every week. The experiment was carried out over $7 \mathrm{wk}$.

Sampling and analysis. Every week and from each enclosure, depth-integrated water samples were collected with a van Dorn bottle to assess concentratins of pelagic chl a (as a proxy for phytoplankton biomass), TN, TP and DOC. Zooplankton was also sampled every week by vertical hauls of $1.6 \mathrm{~m}$ to avoid sediment re-suspension, with a net of $65 \mu \mathrm{m}$ mesh size. Water DOC concentration was measured using a Total Carbon Analyzer (TOC-5000 Shimadzu). TN and TP concentrations were determined by flow injection analysis (FIA). TN was measured after persulfate oxidation and nitrate reduction in a cadmium column with post-nitrite determination (APHA, 1989), and TP was measured using the ammonium-molybdate method after persulfate oxidation (Mackereth et al. 1978). Water transparency was measured as Secchi depth and the light attenuation coefficient was calculated according to Padial \& Thomaz (2008). Periphytic substrates were sampled weekly, stored in plastic containers filled with deionized water to avoid any nutrient contamination, and immediately transferred to the laboratory. The tiles were scraped using a razor blade, and the slurry was adjusted to a defined volume according to Liess \& Hillebrand (2005). The total periphyton biomass and periphyton chl a were determined from the slurry. Total periphyton biomass was estimated as ash-free dry weight (AFDW). The samples were filtered on a pre-combusted GF/F $0.75 \mu \mathrm{m}$ pore filter, and filters were dried at $70^{\circ} \mathrm{C}$ to determin DW. For ash determination, samples were then combusted at $500^{\circ} \mathrm{C}$ for $2 \mathrm{~h}$. Periphyton chl a was estimated using 
a spectrofluorimeter (Li-Cor Turner 3A). Phytoplankton samples were preserved with Lugol's solution, and zooplankton with a $4 \%$ formaldehyde solution. Zooplankters were counted either in a Sedgwick-Rafter chamber under a microscope (rotifers, nauplii, cladocerans \& meroplanktonic larvae) or in open chambers under a stereomicroscope (copepodites \& adult copepods). Total biomass was estimated by weighing 20 individuals of each species (Mettler UMT2 microbalance), except for rotifers whose biomass was obtained as average values from Ruttner-Kolisko (1977). Mean zooplankter weights were multiplied by respective species density in the sample.

Primary production measurement. At Week 3, 5 and 7 we inoculated colonized periphytic substrates in transparent glass flasks with water from substrate depth from each enclosure. The flasks with unfiltered enclosure water and with periphytic substrates plus enclosure water were exposed to sunlight for $\sim 1 \mathrm{~h}$ at a depth of $0.4 \mathrm{~m}$. For these $3 \mathrm{wk}$, light intensities at incubation time (always between 11:00 and 13:00 h) were similar ( $>0.05$, ANOVA), with values around $1000 \mu \mathrm{W}$ $\mathrm{cm}^{-2}$ in air as measured using a portable radiometer (LiCor 50A) at 11:00, 12:00 and 13:00 h. We used these measurements as replicates for each incubation day. We measured planktonic net productivity (dissolved oxygen, DO in $\mathrm{mg} \mathrm{l}^{-1} \mathrm{~h}^{-1}$ ) as the difference in DO concentration between the beginning and the end of the incubations $( \pm 1 \mathrm{~h})$. The DO concentration was measured using a Clark type oxygen microelectrode connected to a pico-amperimeter (PA2000-UNISENSE). Periphyton net productivity was measured as the difference in DO concentration between the beginning and the end of the incubations normalized by incubation time in $\mathrm{h}$ in the flasks with substrates and enclosure water minus the phytoplankton net productivity of the same enclosure. Periphyton net productivity was then expressed per area by multiplying the measured oxygen concentration by the flask volume $(250 \mathrm{ml})$ and dividing by the substrate area $\left(0.015 \mathrm{~m}^{2}\right)$. This method includes gas exchange during day and night and does not provide a good picture of the metabolism of the whole system. It does, however, provide the balance of the potential productivity and respiration rates of both compartments. Thus, we focused on the effects of our manipulations on the potential net community metabolism of both benthic and pelagic compartments rather than on the whole system's metabolism.

At the end of the experiment, all macro-invertebrates associated with the enclosure wall were collected for biomass assessment by dragging a net ( $0.5 \mathrm{~mm}$ mesh size) along the wall. Among these invertebrates, the gastropod Biomphalaria tanegophila was the most common species. We did not estimate its initial densities for this experiment. However, since this species is common on the sediment of Cabiúnas lagoon and no experimental blocking effect on gastropod biomass was observed, we assumed that the snails were evenly distributed among treatment replicates at the beginning of the experiment and that observed final densities were driven by treatment effects. All individuals were dried and weighed with their shells to the nearest $0.1 \mathrm{mg}$ for biomass estimation.

Statistical analysis. To evaluate the individual and interactive effects of time, fish and nutrients on phytoplankton and periphyton net productivity, we analyzed the data using a repeated measures analysis of variance (RM-ANOVA). Measures of time (3 levels wk ${ }^{-1}$ ) were considered to be repeated factors due to temporal dependence (Danger et al. 2008). The main fixed factors in the model included fish (2 levels, present and absent) and nutrients (2 levels, enriched and ambient). A previous analysis was conducted including the experimental blocks (4 levels) as a categorical random factor in the model. Because no significant effect was observed, the experimental blocks were removed from the main analysis. We also used independent models of RM-ANOVA to evaluate statistical differences among treatments for pelagic concentrations of chl $a, \mathrm{TN}, \mathrm{TP}$, water column transparency and periphytic chl $a$ and AFDW. Nutrients and fish were treated as categorical variables, and time as the repeated factor. ContrastAnalysis (CA) was conducted as a post-test to evaluate the differences between treatment levels. Corrections due to the violation in the sphericity assumption were conducted using the Huynh-Feldt adjustment. To evaluate Biomphalaria tenagophyla biomass differences, we used a 2-way ANOVA with a HSD Tukey post-hoc test without the block effect, after we determined that it was not significant $(F=1.293, \mathrm{p}>0.05$, ANOVA). We also used a 2-way ANOVA to test differences in the biomass of specific zooplankton groups among treatments. To reduce the heterogeneity of the variances, the data were $\log _{10^{-}}$transformed. All statistical analyses were performed using STATISTICA 8.0 software for Windows. We also calculated the standardized mean difference $(D)$ as an effect size statistic to evaluate the strength of the effects of fish and nutrient addition on planktonic and periphytic net productivity. For $D$, the difference between 2 treatment means is standardized by the pooled standard deviation of both treatments (Gurevich \& Hedges 1993). Effect sizes of Fish, Nut and Fish+Nut were calculated for the $3 \mathrm{wk}$. The effect sizes obtained for each wk were combined using a fixed effects model to calculate a cumulative effect size throughout the experimental period for each treatment. Statistical inferences regarding average effect sizes were performed by calculating the $95 \%$ inter-quartile of the bootstrapped main effect size with 4999 permutations as confidence intervals (CI). The 
effect sizes and CIs were calculated using Metawin 2.1 software (Rosenberg et al. 2000).

We developed a set of generalized linear models (GLZ), which are suitable for the different types of predictors described above in order to establish plausible mechanisms that explain phytoplankton and periphyton net productivity. In order to select the best approximating model for our data, we calculated Akaike's Information Criterion (AIC) and then the second-order AIC (AICc), which is necessary for a small sample (Johnson \& Omland 2004). We used zooplankton biomass, phytoplankton biomass and TP concentration to evaluate the best models that predict planktonic net productivity, and for periphytic net productivity we chose light extinction coefficient, total phosphorus concentration, periphytic chl a concentration and the chl a:AFDW ratio (hereafter autotrophic index $=\mathrm{AI}$ ) as model candidates. Changes on TP concentration among weeks were mainly driven by inorganic nutrients used to adjust nutrient concentration over the experiment. We did not use TN concentration as a predictive model because it was highly correlated with TP concentrations and because phosphorus has been identified as the major limiting nutrient of coastal ecosystems processes (Sundareshwar et al. 2003), the same applying to Cabiúnas Lagoon (Farjalla et al. 2002). Although autotrophic biomass may be directly related to gross primary productivity, such relationship may be not so trivial when considering net productivity, due to the balance between production and respiration. For this reason we chose phytoplankton and periphyton chl a as model candidate. We were not able to use gastropod density in the model selection inference because we only had data available for the end of the experiment. We used SAM 3.1 software to conduct model selection inference (Rangel et al. 2006).

\section{RESULTS}

\section{Biotic and abiotic variables}

Variables are summarized in Fig. 1. Phytoplankton biomass was significantly higher in treatments with
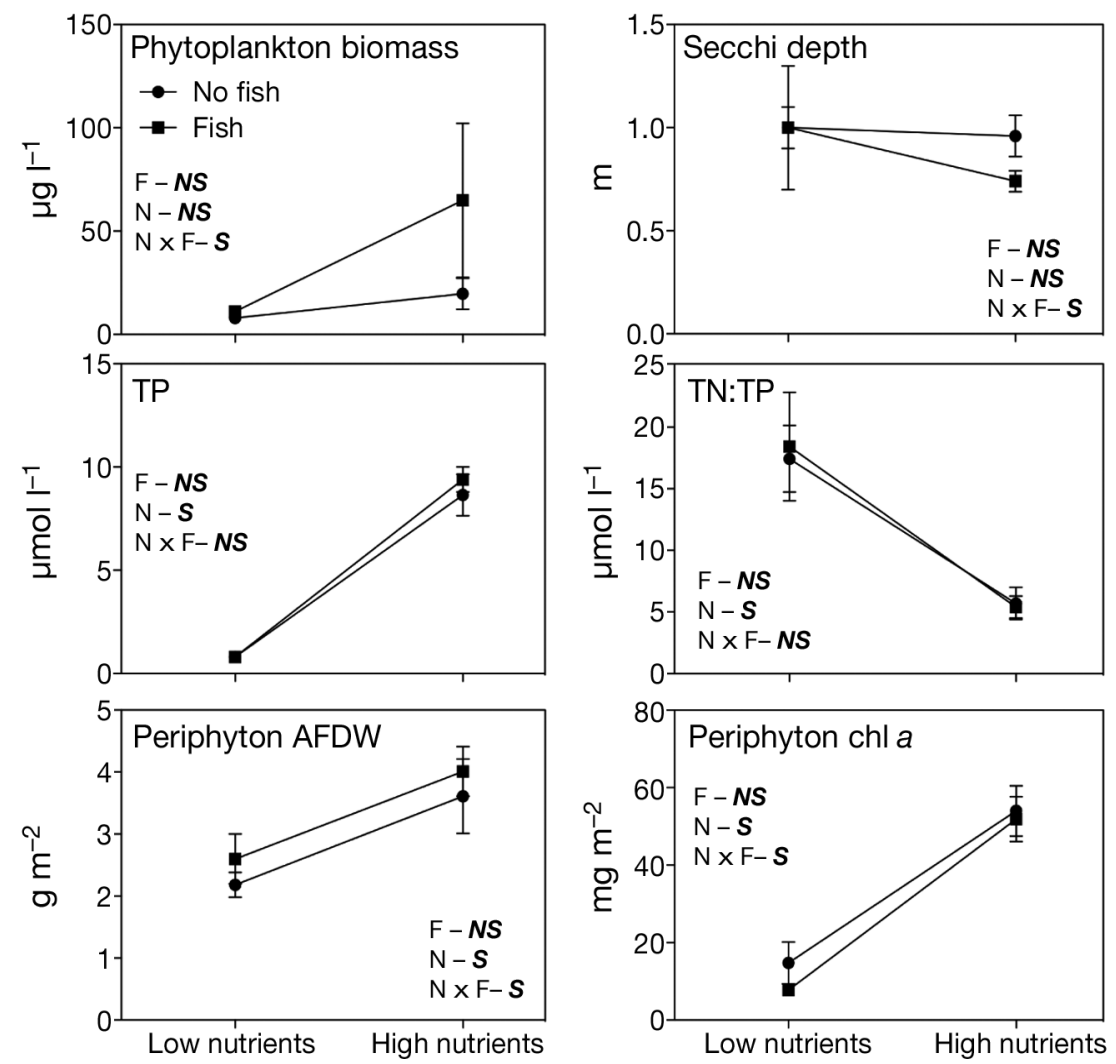
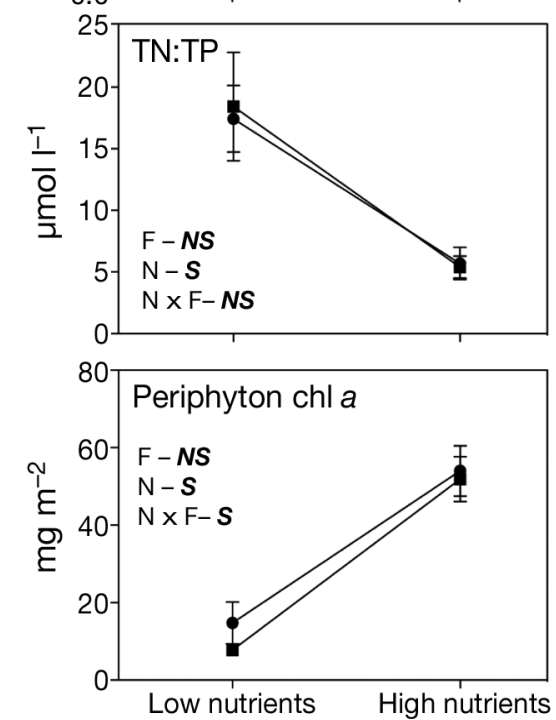
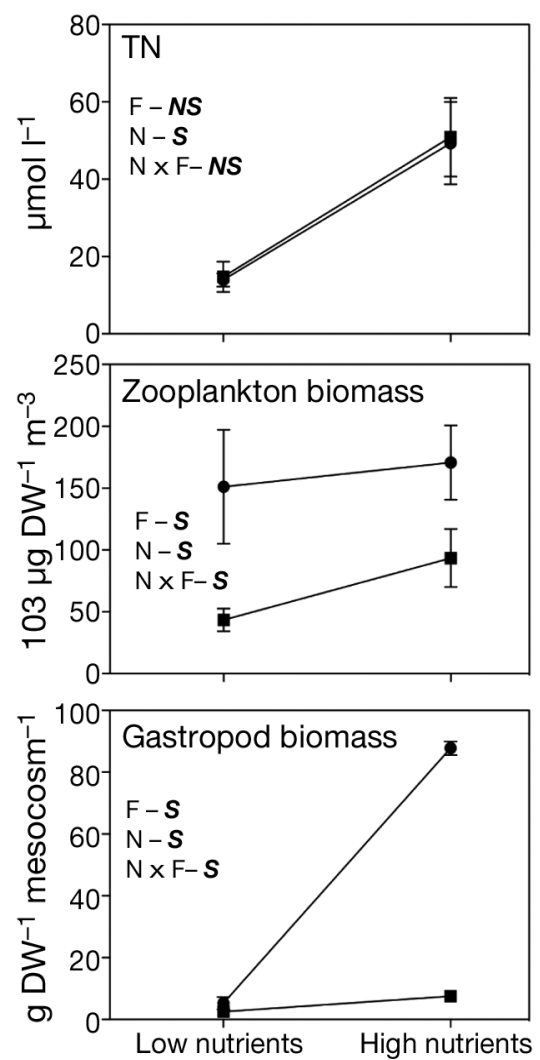

Fig. 1. Biotic and abiotic variables among the experimental treatments. Each panel represents the change of 1 response variable for the $7 \mathrm{wk}$ study period. Phytoplankton biomass = chl a concentrations; Secchi depth = water transparency; TN = total nitrogen; $\mathrm{TP}=$ total phosphorus; Periphyton chl $a$ = Periphyton chlorophyll $a$ content; Periphyton AFDW = Periphytic biomass as ash free dry weight. All values are means \pm SE. For each variable, statistical inferences are represented by the letters $\mathrm{F}$ (fish treatment), $\mathrm{N}$ (nutrient treatment) and $\mathrm{N} \times \mathrm{F}$ (nutrient and fish interaction). $\boldsymbol{S}=$ treatment had a significant effect; $\boldsymbol{N S}=$ non-significant effect $(\alpha=0.05$, RM-ANOVA) 
nutrient addition, especially in the presence of fish, i.e. reduced Secchi depth. Both TN and TP concentrations were significantly higher with nutrient addition. Average concentrations in the enclosures, without or with nutrient addition, were 13 or $50 \mu \mathrm{mol}^{-1}$ for $\mathrm{TN}$, and 0.8 or $9.4 \mathrm{mmol}^{-1}$ for $\mathrm{TP}$, respectively. Nutrient addition changed the $\mathrm{N}: \mathrm{P}$ ratio in the water to about 5:1.

Zooplankton biomass increased with the addition of nutrients, but decreased with the addition of fish. Also, fish significantly affected zooplankton composition (Fig. 2), reducing the abundance of Cladocera and Calanoida crustaceans $(\mathrm{p}=0.0289,2$-way ANOVA) and increasing the abundance of small-bodied zooplankton species such as rotifers $(p=0.0427$, 2-way ANOVA). Such effects of fish on zooplankton were pronounced in high nutrient conditions. Average periphytic AFDW was primarily affected by nutrient addition, and periphytic chl a content was significantly affected by fish and nutrients, but no significant interaction was observed between the 2 factors. However, for both periphytic AFDW and chl a concentrations, the RM-ANOVA models revealed significant interactive effects of time with fish presence and nutrient addition. Fish presence positively affected periphytic AFDW after Week 4 of the experiment (Time $\times$ Fish, $\mathrm{p}<0.001, F=8.31$, RM-ANOVA) but also promoted a reduction of ca. $20 \%$ in the average periphytic chl a content after Week 5 when comparing Nut vs. Fish+Nut treatments (df =1, $F=$ 3.340, $\mathrm{p}=0.049, \mathrm{CA}$ ). Finally, gastropod biomass was distinctly higher in the treatment with only $\mathrm{N}$ and $\mathrm{P}$ addition presenting similar values across all remaining treatments.

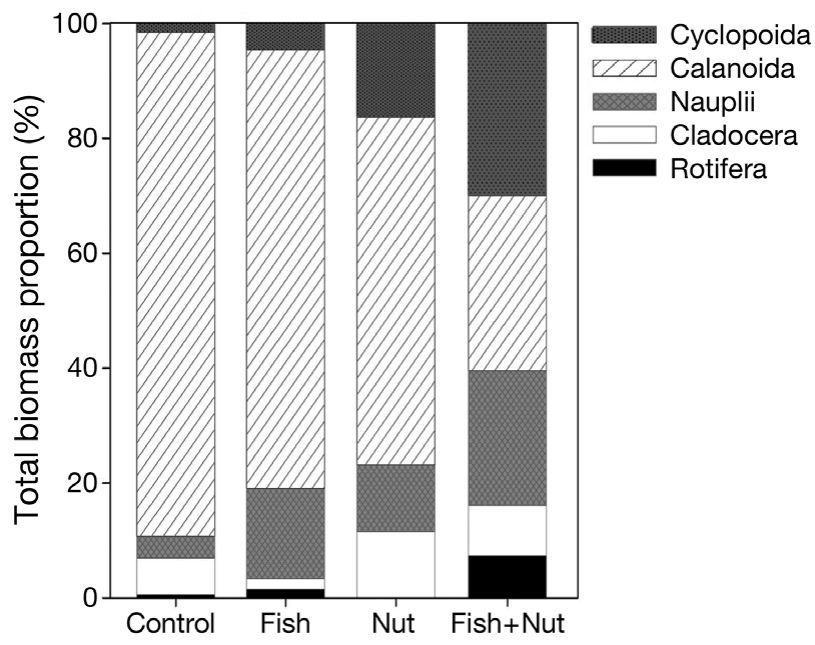

Fig. 2. Zooplankton groups. Relative abundance in each treatment after 7 wk. Control $=$ no fish, no nutrients added; Fish: only fish added; Nut: only nutrients added; Fish+Nut: both fish and nutrients added

\section{Net ecosystem productivity}

Fish and nutrient addition had positive effects on planktonic net productivity (Table 2), and the highest net productivity values were observed in the treatment with the joint addition of fish and nutrients (Fig. 3). The average effect of Nut and Fish+Nut treatments were greater than for Fish alone (Fig. 4), although they were not significant. The AICc selected $\mathrm{TP}, \mathrm{TP}+$ zooplankton biomass, TP + zooplankton biomass + phytoplankton biomass as the best models explaining planktonic net productivity (Table 3). Because these models are nested and share small differences between the AICc values, we concluded that all of these variables are important in determining planktonic net productivity.

Table 2. Univariate factorial within-subject ANOVA for plankton and periphyton net productivity. The F-ratio and p-values for all main factors and their interactions are shown. p-values for within-subjects were corrected by the HuynhFeldt adjustment. Bold: significant treatment effects $(\mathrm{p}<0.05)$

\begin{tabular}{|lcccrc|}
\hline \multirow{2}{*}{ Factor } & \multicolumn{5}{c|}{ Net production } \\
\cline { 2 - 5 } & \multicolumn{3}{c}{ Plankton } & \multicolumn{2}{c|}{ Periphyton } \\
& $F$ & $\mathrm{p}$ & $F$ & $\mathrm{p}$ \\
\hline Fish (F) & $\mathbf{6 . 9 8}$ & $\mathbf{0 . 0 2 6 7}$ & $\mathbf{5 . 4 2 2}$ & $\mathbf{0 . 0 3 8 1}$ \\
Nutrient (N) & $\mathbf{1 0 . 2 4 1}$ & $\mathbf{0 . 0 0 2 0}$ & 0.460 & 0.5101 \\
$\mathrm{~F} \times \mathrm{N}$ & $\mathbf{4 . 3 2 4}$ & $\mathbf{0 . 0 3 2 5}$ & 0.034 & 0.8555 \\
Time $(\mathrm{T})$ & $\mathbf{1 0 . 5 7 1}$ & $\mathbf{0 . 0 0 0 5}$ & $\mathbf{6 . 4 5 4}$ & $\mathbf{0 . 0 0 5 7}$ \\
$\mathrm{T} \times \mathrm{F}$ & $\mathbf{3 . 3 9 2}$ & $\mathbf{0 . 0 4 5 3}$ & $\mathbf{4 . 2 0 8}$ & $\mathbf{0 . 0 2 7 1}$ \\
$\mathrm{T} \times \mathrm{N}$ & 3.206 & 0.0583 & $\mathbf{3 . 8 1 8}$ & $\mathbf{0 . 0 3 6 3}$ \\
$\mathrm{T} \times \mathrm{F} \times \mathrm{N}$ & 0.118 & 0.8885 & 0.002 & 0.9980 \\
& & & & & \\
\hline
\end{tabular}

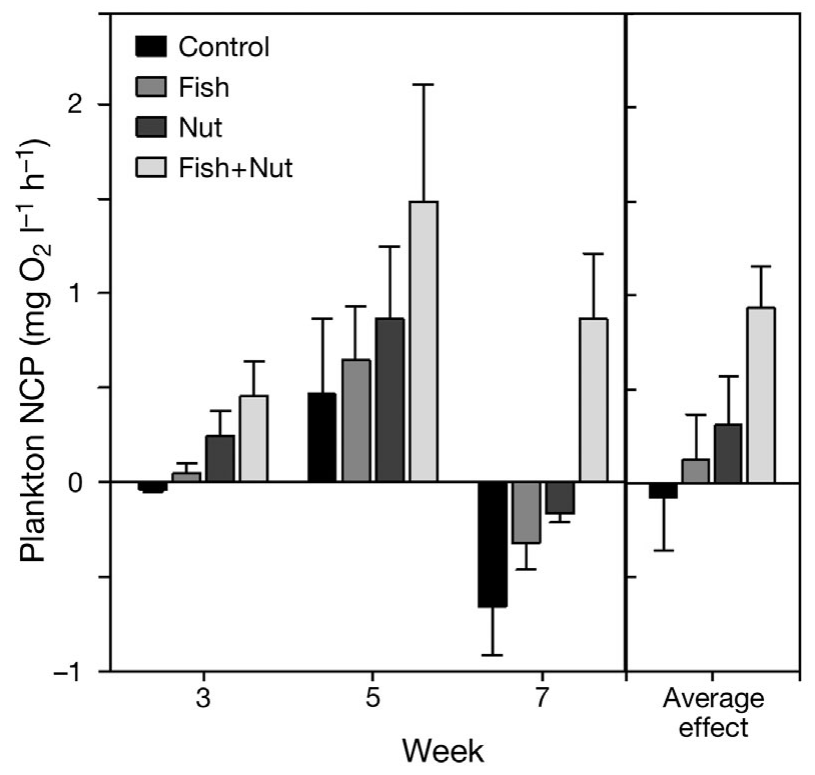

Fig. 3. Plankton net community productivity (NCP) for Weeks 3, 5 and 7 of the experiment and averaged across all weeks (mean $\pm \mathrm{SE}$ ). Abbreviations as in Fig. 2 


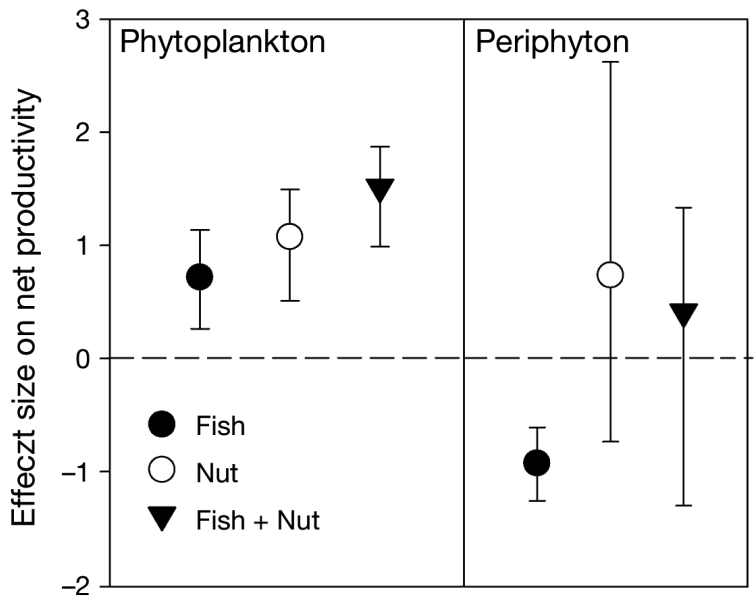

Fig. 4. Effect sizes of treatments on phytoplankton and periphyton net productivity (NP) throughout the experiment. Symbols $=$ mean \pm bootstrapped $95 \%$ CI. Abbreviations as in Fig. 2

Table 3. Models of plankton net productivity and Akaike selection criterion values. AICcwi represents the Akaike weight of the model. Bold $=$ models with $\Delta \mathrm{AICc}<2$. Phyto $=$ phytoplankton biomass; Zoo $=$ zooplankton biomass; $\mathrm{TP}=$ total phosphorus

\begin{tabular}{|lccc|}
\hline Variables & AICC & $\Delta$ AICC & AICcwi \\
\hline TP & $\mathbf{2 3 . 1 4 3}$ & $\mathbf{0 . 0 0}$ & $\mathbf{0 . 3 7 9}$ \\
Zoo, TP & $\mathbf{2 3 . 4 6 5}$ & $\mathbf{0 . 3 2}$ & $\mathbf{0 . 3 2 2}$ \\
Zoo, Phyto, TP & $\mathbf{2 5 . 0 9 4}$ & $\mathbf{1 . 9 5}$ & $\mathbf{0 . 1 4 3}$ \\
Phyto, TP & 25.397 & 2.25 & 0.123 \\
Phyto & 28.766 & 5.62 & 0.023 \\
Zoo, Phyto & 31.108 & 7.97 & 0.007 \\
Zoo & 32.35 & 9.21 & 0.004 \\
\hline
\end{tabular}

Addition of both $\mathrm{N}$ and $\mathrm{P}$ were positive overall but this trend was not consistent throughout the experiment, which can be verified by the significant interaction between nutrients and time (Table 2, Fig. 5). However, in contrast to results for the planktonic communities, no interactions between fish and nutrients were observed regarding periphyton biomass. In general, the effect of fish on periphytic net productivity was significantly negative (Table 2, Fig. 4). The model selection inference for periphytic net productivity is provided in Table 4 . According to the AICc, the AI + chl $a$ content and chl a content alone were selected as the best models. Therefore, we concluded that these 2 variables were important in determining the observed periphytic net productivity.

No linear correlation was found between overall planktonic or periphytic net productivity (Fig. 6). The Pearson correlation coefficient was -0.257 , which means that these variables might be negatively correlated, though this trend was not significant $(p=0.084)$.

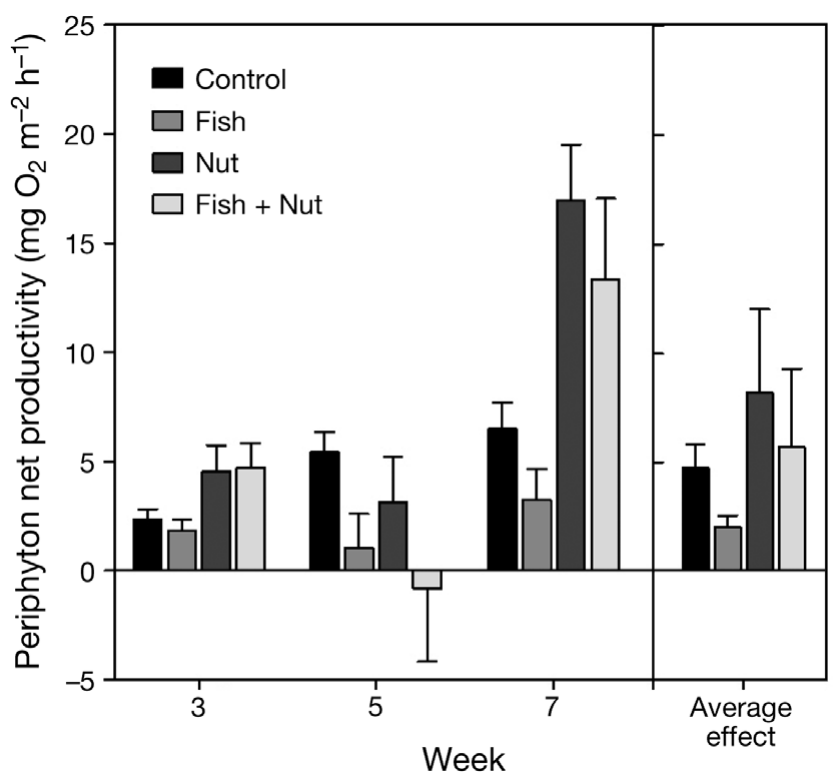

Fig. 5. Periphyton net community productivity (NCP) for Weeks 3, 5 and 7 of the experiment and averaged across all weeks. Columns $=$ means + SE. Abbreviations as in Fig. 2

Table 4. Models of periphyton net productivity and Akaike selection criterion values. AICcwi represents the Akaike weight of the model. Bold $=$ models with $\triangle \mathrm{AICc}<2$. Chl $a=$ Autotrophic periphytic biomass; IA = periphytic chl a:AFDW ratio; $\mathrm{TP}=$ Total phosphorus $; k=$ light extinction coefficient

\begin{tabular}{|c|c|c|c|}
\hline Variables & $\mathrm{AICc}$ & $\Delta \mathrm{AICC}$ & AICcwi \\
\hline AI, chl a & 26.558 & $\mathbf{0}$ & 0.313 \\
\hline Chl a & 27.266 & 0.709 & 0.22 \\
\hline IA, TP, chl a & 28.782 & 2.225 & 0.103 \\
\hline $\mathrm{TP}, \mathrm{chl}$ a & 28.923 & 2.366 & 0.096 \\
\hline$k, \mathrm{IA}, \operatorname{chl} a$ & 29.056 & 2.498 & 0.09 \\
\hline$k, \operatorname{chl} a$ & 29.49 & 2.933 & 0.072 \\
\hline$k, \mathrm{TP}, \mathrm{chl} a$ & 30.771 & 4.213 & 0.038 \\
\hline$k, \mathrm{IA}, \mathrm{TP}, \mathrm{chl} a$ & 31.245 & 4.688 & 0.03 \\
\hline TP & 33.426 & 6.869 & 0.01 \\
\hline IA & 33.829 & 7.271 & 0.008 \\
\hline$k$, IA & 34.767 & 8.21 & 0.005 \\
\hline$k$ & 34.793 & 8.235 & 0.005 \\
\hline$k, \mathrm{TP}$ & 35.299 & 8.741 & 0.004 \\
\hline IA, TP & 35.427 & 8.87 & 0.004 \\
\hline$k, \mathrm{IA}, \mathrm{TP}$ & 37.186 & 10.629 & 0.002 \\
\hline
\end{tabular}

\section{DISCUSSION}

In our experiment, the presence of fish positively affected planktonic net productivity, especially under nutrient enriched conditions. This supports our first hypothesis that fish effects on phytoplankton net primary productivity will be stronger under non-limiting nutrient levels. Top predators (e.g. fish) can positively affect periphytic (Goldschmidt et al. 1993, McCollum et al. 1998) or pelagic (Vanni \& Findlay 1990, Pace et 


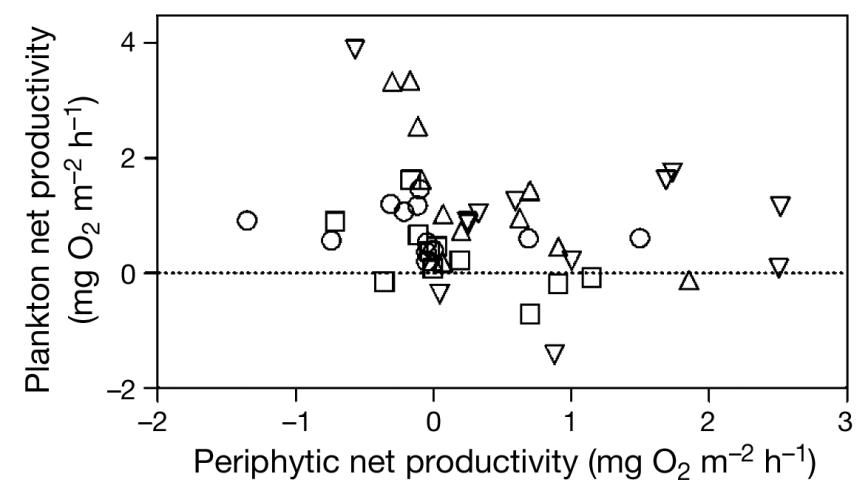

Fig. 6. Correlation between planktonic and periphytic NCP across all sampling weeks and treatments. Symbols denote individual enclosures at a given time. O: Control, $\square$ : Fish, $\Delta:$ Nut, $\nabla:$ Fish + Nut. Abbreviations as in Fig. 2

al. 1999) producers as well as ecosystem net productivity (Schindler et al. 1997, Huryn 1998). However, our results showed that fish addition lowered periphytic net productivity. This confirms our second hypothesis, that fish presence allows the accumulation of pelagic algal biomass by enhancing phytoplankton net productivity but decreases periphyton net productivity.

Despite the notion that nutrient enhancement tends to increase the magnitudes of both gross primary production (GPP) and respiration (Cole et al. 2000), which limits any prediction of net productivity, ecosystem net productivity tends to track chl a concentrations (delGiorgio \& Peters 1994). Thus, the net productivity in oligotrophic and humic lakes such as Cabiúnas lagoon should be enhanced with nutrient loading due to its overwhelming importance on the biomass of primary producers. However, the positive effect of nutrient enrichment on planktonic net productivity was consistent throughout the experiment only in the treatment with the joint addition of fish (Fig. 3). We believe that this pattern is a result of the interaction of bottom-up and top-down effects on phytoplankton biomass. Cole et al. (2000) highlighted that the dominance of largebodied zooplankton, particularly Daphnia, can limit the propagation of nutrient effects on net ecosystem productivity and can maintain overall ecosystem heterotrophy even with nutrient addition. In the present study, fish presence reduced zooplankton biomass and promoted a shift in the zooplankton community composition, especially in high nutrient conditions. We observed a decrease in the abundance of large-bodied zooplankters and an increase in the abundance of small-bodied groups, which are less efficient in controlling phytoplankton biomass (Romare et al. 1999, Levine et al. 2005), thereby enhancing phytoplanktonic biomass and consequently planktonic net productivity in the Fish+Nut treatment.
Although nutrient excretion by fish may significantly affect primary producer biomass (Lövgren \& Persson 2002, Vanni 2002), in the present study fish nutrient recycling possibly had minor importance because the effect of fish was greater when nutrients were abundant and fish presence did not significantly affect average TP, TN or TN:TP ratio in the enclosures (Fig. 1). Thus, we conclude that the indirect positive effects of fish on primary producers were primarily determined by trophic cascade mechanisms highlighted above.

In general, periphytic autotrophic biomass is positively affected by the incidence of benthivorous fish (Power 1990, McCollum et al. 1998), which may be attributed to trophic cascade interactions. Compared to the Nut treatment, fish presence significantly reduced grazer (Biomphalaria tenagophyla) biomass and promoted a slight increase of average periphyton AFDW. However, the presence of fish had a negative effect on periphytic net productivity even under high nutrient conditions. We believe that this contrasting effect may be attributed to 2 non-exclusive mechanisms: (1) fish foraging behavior; and (2) asymmetric competition between periphyton and pelagic producers. Under low nutrient conditions, the availability of optimal prey types (e.g. zooplankton and benthic macro-invertebrates, Fig. 1) is reduced and fish may directly access periphytic biomass. Gelwick \& Matthews (1992) showed that fish can selectively feed on periphyton, exerting greater herbivory on more prostrated algae forms. By directly feeding on loosely attached algae, which were an important component of periphyton in our experiment (visual observation), fish presence reduced periphytic autotrophic biomass content and consequently periphytic net productivity. By directly assessing periphytic biomass, fish may also promote a shift in algal community composition from more vulnerable and fast-growing species to more resistant species (Darcy-Hall 2006), thus reducing the turnoverrate of the community which negatively affects periphytic net productivity (Kaehler \& Froneman 2002, Abe et al. 2007). Singer \& Bernays (2003) point out that food quality or quantity may be decisive constraints affecting the occurrence of the omnivorous behavior of fish, which is crucial to the structure and function of the food web. Under high nutrient conditions, optimal prey types are abundant and the food web may become less reticulated with a reduction in fish diet diversification, such as a decline in periphyton consumption. Nevertheless, reduced herbivory on phytoplankton due to fish predation on zooplankton can negatively affect periphyton autotrophic biomass and consequently periphyton net productivity by reducing the light availability to the periphytic community. Consequently, the exploitative competition between benthic and pelagic producers is enhanced (Hansson 1992, 
Flöder et al. 2006), as demonstrated in our study by the significant reduction of Secchi depth in the Fish+Nut treatment.

We did not observe a significant relationship between phytoplanktonic and periphytic net productivity, and the process driving this pattern could be better assessed by the model selection analysis. Phytoplankton net productivity was better described by phosphorus availability, but zooplankton biomass and phytoplankton biomass were also important predictors. On the other hand, periphytic net productivity was better described by the autotrophic periphytic biomass and the relative contribution of autotrophic biomass to the periphyton total biomass. Although distinct, some predictor variables in these 2 models are analogous and in agreement with previous assessments of the metabolism of aquatic ecosystems. Net productivity is dependent on GPP, which is generally a function of the autotrophic biomass (e.g. phytoplankton biomass and periphytic biomass as chl a) (delGiorgio et al. 1997, Cole et al. 2000). Zooplankton biomass was also an important predictor of phytoplankton net productivity, which may be attributed to the reduction in phytoplankton biomass by zooplankton grazing and consequently net phytoplankton productivity. In addition, community net productivity can be a function of system respiration that, in turn, can be thought as the relative contribution of heterotrophic organisms to the community, which is represented, indirectly, by the AI in our analysis. However, the likelihood of TP contributing to a predictive model of periphytic net productivity was lower than that of planktonic net productivity (Tables $3 \& 4$ ). In fact, nutrients are poor indicators of periphytic production (DeNicola et al. 2003, Liboriussen \& Jeppesen 2006, Vadeboncoeur et al. 2008) particularly because water-column nutrient concentrations are poor indices of the total nutrient pool available to benthic algae, which includes nutrients recycled within the biofilm (McCormick et al. 2001). Furthermore, water column nutrients are strongly correlated with phytoplankton biomass and, thus, are negatively correlated with the availability of light, which constrains benthic producers' biomass (Vadeboncoeur et al. 2008). Consequently, this sort of effect directly influences the relationship between planktonic and periphytic net productivity and, as shown above, this effect can be intensified in the presence of fish.

The introduction of predatory fish has been shown to enhance ecosystem level productivity of lakes because of cascading trophic interactions (Goldschmidt et al. 1993, Schindler et al. 1997, Huryn 1998). However, our results shed light on how the natural food web complexity may change the expected response of ecosystem metabolism to nutrients and food web manipulations if periphyton can significantly contribute to overall system metabolism. Future work should focus on establishing if the reduction in benthic net productivity induced by food web structure can alter whole system metabolism, particularly in lakes with highly developed littoral zones.

Acknowledgements. The authors are grateful to the staff of the Laboratory of Limnology of the Federal University of Rio de Janeiro for their full assistance. They are also in debt to Carolyn Burns and 3 anonymous reviewers who strongly improved the quality of the manuscript. Financial support and scholarships were provided by CNPq, Petrobras and CAPES.

\section{LITERATURE CITED}

Abe SI, Uchida K, Nagumo T, Tanaka J (2007) Alterations in the biomass-specific productivity of periphyton assemblages mediated by fish grazing. Freshw Biol 52: 1486-1493

APHA (American Public Health Association) (1989) American Public Health Association, standard methods for the examination of water and wastewater (17th edn). American Public Health Association, Washington, DC

> Bascompte J, Melian CJ, Sala E (2005) Interaction strength combinations and the overfishing of a marine food web. Proc Natl Acad Sci USA 102:5443-5447

Carvalho TP, Bertaco VA (2006) Two new species of Hyphessobrycon (Teleostei: Characidae) from the upper rio Tapajos basin on Chapada dos Perecis, Central Brazil. Neotrop Ichthyol 3:301-308

Cole JJ, Pace ML, Carpenter SR, Kitchell JF (2000) Persistence of net heterotrophy in lakes during nutrient addition and food web manipulations. Limnol Oceanogr 45: 1718-1730

Cotner JB, Biddanda BA (2002) Small players, large role: Microbial influence on biogeochemical processes in pelagic aquatic ecosystems. Ecosystems 5:105-121

> Danger M, Lacroix G, Oumarou C, Benest D, Mériguet J (2008) Effects of food-web structure on periphyton stoichiometry in eutrophic lakes: a mesocosm study. Freshw Biol 53:2089-2100

> Darcy-Hall TL (2006) Relative strengths of benthic algal nutrient and grazer limitation along a lake productivity gradient. Oecologia 148:660-671

> del Giorgio PA, Peters RH (1994) Patterns in planktonic P:R ratios in lakes: influence of lake trophy and dissolved organic carbon. Limnol Oceanogr 39:772-787

del Giorgio PA, Cole JJ, Cimbleris A (1997) Respiration rates in bacteria exceed phytoplankton production in unproductive aquatic systems. Nature 385:148-151

> DeNicola DM, de Eyto E, Wemaere A, Irvine K (2003) Production and respiration of epilithic algal communities in Irish lakes of different trophic status. Arch Hydrobiol 157:67-87

> Elser JJ, Goldman CR (1991) Zooplankton effects on phytoplankton in lakes of contrasting trophic status. Limnol Oceanogr 36:64-90

Esteves FA, Caliman A, Santangelo JM, Guariento RD, Farjalla VF, Bozelli RL (2008) Neotropical coastal lagoons: an appraisal of their biodiversity, functioning, threats and conservation management. Braz J Biol 68:967-981

> Farjalla VF, Faria BM, Esteves FA (2002) The relstionship between DOC and planktonic bacteria in tropical coastal lagoons. Arch Hydrobiol 156:97-119

Flöder S, Combüchen A, Pasternak A (2006) Competition 
between pelagic and benthic microalgae for phosphorus and light. Aquat Sci 68:425-433

Gelwick FP, Matthews WJ (1992) Effects of an algivorous minnow on temperature stream ecosystem properties. Ecology 73:1630-1645

Goldschmidt T, Witte F, Wanink J (1993) Cascading effects of the introduced Nile perch on the detritivorous phytoplanktivorous species in the sublittoral areas of Lake Victoria. Conserv Biol 7:686-700

Guariento RD, Caliman A, Esteves FA, Bozelli RL, EnrichPrast A, Farjalla VF (2009) Substrate influence and temporal changes on periphytic biomass accrual and metabolism in a tropical humic lagoon. Limnologica 39:209-218

Gurevich J, Hedges LV (1993) Meta-Analysis: combining the results of independent experiments. In: M. SS, J. G (eds) Design and Analysis of Ecological Experiments. CRC Press, Boca Raton, FL, p 378-398

Hansson LA (1992) The role of food-chain composition and nutrient availability in shaping algal biomass development. Ecology 73:241-247

Hillebrand H (2002) Top-down versus bottom-up control of autotrophic biomass - a meta-analysis on experiments with periphyton. J N Am Benthol Soc 21:349-369

Huryn AD (1998) Ecosystem-level evidence for top-down and bottom-up control of production in a grassland stream system. Oecologia 115:173-183

Huszar VLM, Caraco NF, Roland F, Cole J (2006) Nutrientchlorophyll relationships in tropical subtropical lakes: Do temperate models fit? Biogeochemistry 79:239-250

Johnson JB, Omland KS (2004) Model selection in ecology and evolution. Trends Ecol Evol 19:101-108

Kaehler S, Froneman PW (2002) Herbivore-mediated increase in the photosynthetic capacity of marine biofilms: indirect effects of changing microalgal assemblage composition. Mar Ecol Prog Ser 234:15-22

Kjerfve B (1994) Coastal lagoon processes. In: Kjerfve B (ed) Coastal lagoon processes. Elsevier Oceanographic Series, New York, NY

Levine SN, Zehrer RF, Burns CW (2005) Impact of resuspended sediment on zooplankton feeding in Lake Waihola, New Zealand. Freshw Biol 50:1515-1536

Liboriussen L, Jeppesen E (2006) Structure, biomass, production and depth distribution of periphyton on artificial substratum in shallow lakes with contrasting nutrient concentrations. Freshw Biol 51:95-109

Liess A, Hillebrand H (2005) Stoichiometric variation in C: N, C: $\mathrm{P}$, and N: P ratios of littoral benthic invertebrates. $\mathrm{J} \mathrm{N}$ Am Benthol Soc 24:256-269

Lövgren J, Persson L (2002) Fish-mediated indirect effects in a littoral food web. Oikos 96:150-156

Mackereth FJH, Heron J, Talling JF (1978) Water analysis: some revised methods for limnologists. Sci Publ Freshw Biol Assoc No 21

Mazumder A, Lean DRS (1994) Consumer-dependent responses of lake ecosystems to nutrient loading. J Plankton Res 16:1567-1580

> McCollum EW, Crowder LB, McCollum SA (1998) Complex interactions of fish, snails, and littoral zone periphyton. Ecology 79:1980-1994

McCormick PV, O'Dell MB, Shuford RBE, Backus JG, Kennedy WC (2001) Periphyton responses to experimental phosphorus enrichment in a subtropical wetland. Aquat Bot 71:119-139

Pace ML, Cole JJ, Carpenter SR, Kitchell JF (1999) Trophic cascades revealed in diverse ecosystems. Trends Ecol Evol

\section{4:483-488}

> Padial AA, Thomaz SM (2008) Prediction of the light attenuation coefficient through the Secchi disk depth: empirical modeling in two large Neotropical ecosystems. Limnology 9:143-151

Polis GA, Strong DR (1996) Food web complexity and community dynamics. Am Nat 147:813-846

Power ME (1990) Resource enhancement by indirect effects of grazers:armored catfish, algae, and sediment. Ecology 71:897-904

> Rangel T, Diniz-Filho JAF, Bini LM (2006) Towards an integrated computational tool for spatial analysis in macroecology and biogeography. Glob Ecol Biogeogr 15:321-327

> Romare P, Bergman E, Hansson LA (1999) The impact of larval and juvenile fish on zooplankton and algal dynamics. Limnol Oceanogr 44:1655-1666

Rosenberg MS, Adams DC, Gurevich J (2000) MetaWin: statistical software for meta-analysis. Sinauer Associates, Sunderland, MA

Ruttner-Kolisko A (1977) Suggestions for biomass calculation of plankton rotifers. Arch Hydrobiol Beih Ergebn Limnol 8:71-76

> Sánchez-Botero JI, Caramaschi EP, Garcez DS (2008) Spatiotemporal variation in fish assemblage in a coastal lagoon without direct contact with the sea (southeastern Brazil). J Coast Res 24:225-238

> Schindler DE, Scheuerell MD (2002) Habitat coupling in lake ecosystems. Oikos 98:177-189

> Schindler DE, Carpenter SR, Cole J, Kitchell JF, Pace ML (1997) Influence of food web structure on carbon exchange between lakes and the atmosphere. Science 277:248-251

Shurin JB, Borer ET, Seabloom EW, Anderson K and others (2002) A cross-ecosystem comparison of the strength of trophic cascades. Ecol Lett 5:785-791

Singer MS, Bernays EA (2003) Understanding omnivory needs a behavioral perspective. Ecology 84:2532-2537

> Stephen D, Balayla DM, Collings SE, Moss B (2004) Two mesocosm experiments investigating the control of summer phytoplankton growth in a small shallow lake. Freshw Biol 49:1551-1564

Sundareshwar PV, Morris JT, Koepfler EK, Fornwalt B (2003) Phosphorus limitation of coastal ecosystem processes. Science 299:563-565

> Thiengo SC, Fernandez MA, Boaventura MF, Santos SB, Mattos AC (2002) Freshwater snails and Schistosomiasis mansoni in the State of Rio de Janeiro, Brazil: II - Centro Fluminense Mesoregion. Mem Inst Oswaldo Cruz 97:621-626

Vadeboncoeur Y, Vander Zanden MJ, Lodge DM (2002) Putting the lake back together: reintegrating benthic pathways into lake food web models. Bioscience 52:44-54

Vadeboncoeur Y, McCann K, Zanden M, Rasmussen J (2005) Effects of multi-chain omnivory on the strength of trophic control in lakes. Ecosystems 8:682-693

Vadeboncoeur Y, Peterson G, Vander Zanden MJ, Kalff J (2008a) Benthic algal production across lake size gradients: interactions among morphometry, nutrients, and light. Ecology 89:2542-2552

> Vanni MJ (2002) Nutrient cycling by animals in freshwater ecosystems. Annu Rev Ecol Syst 33:341-370

> Vanni MJ, Findlay DL (1990) Trophic cascades and phytoplankton community structure. Ecology 71:921-937

Wetzel RG (1990) Land-water interfaces: metabolic and limnological indicators. Verh Int Ver Theor Angew Limnol 24:6-24 